\title{
NYELVTÖRTÉNET ÉS HUMÁNGENETIKA
}

\section{HISTORICAL LINGUISTICS AND GENETICS}

\author{
Bakró-Nagy Marianne \\ az MTA doktora, tudományos tanácsadó, egyetemi tanár, MTA Nyelvtudományi Intézet, Szegedi Tudományegyetem \\ Finnugor Tanszék, Szeged \\ bakro.marianne@nytud.mta.hu
}

\begin{abstract}
ÖSSZEFOGLALÁS
E rövid áttekintés a humángenetika és a történeti és összehasonlító nyelvészet leglényegesebb módszertani különbségeire világít rá annak érdekében, hogy tisztázza, miért problematikus beszélői közösségek genetikai viszonyaiból következtetni azok nyelvi rokonságára. Először példaként indián nyelvek, illetve tonális nyelvek rokonságára vonatkozó hibás következtetéseket mutat be, majd indonéziai és bantu nyelvek példáján szemlélteti, miként lehet ígéretes a két tudományág együttműködése.
\end{abstract}

\section{ABSTRACT}

This short overview seeks to highlight the most crucial differences between the methodology of human genetics and historical and comparative linguistics in order to explain why it is problematic to assume the relatedness of languages based on the genetic relatedness of speech communities. This point is highlighted first by providing examples of misleading conclusions concerning the relationship of the Amerindian languages and languages displaying tonality, and second, it is demonstrated through the examples of Indonesian and Bantu languages in what respects collaboration between the two disciplines can be fruitful.

Kulcsszavak: történeti és összehasonlító nyelvészet, nyelvrokonság

Keywords: historical and comparative linguistics, genetic relationship of languages

1. Tagadhatatlan, hogy a humángenetika együttmüködése a történeti nyelvészettel elvileg lehetőséget kínálhat prehistorikus folyamatok jobb megértéséhez, hiszen a gének és a kultúra, s benne a nyelv, egyaránt társadalmi kapcsolatok, folyamatok révén öröklődnek egyik generációról a másikra. Az azonban, hogy egyenes korreláció állna fenn valamely nyelv története és a nyelvet beszélők genetikai leszármazása között, több szempontból is igazolhatatlan feltételezés. Míg a genetikai állomány átöröklése kizárólag vertikális úton történhetik, addig a nyelv 
átörökítése éppúgy lehet vertikális, mint (nyelvi kapcsolatok következtében) horizontális, s ez utóbbival összefüggésben: míg az embernek csak egyetlen génállománya lehet, addig nyelve kettő is vagy éppen több. (Tudvalévő, hogy a világ lakosságának többsége - iskolázottságtól függetlenül - többnyelvủ.) Ismeretes továbbá az is, hogy a kultúra s benne a nyelv változása jóval gyorsabb ütemben zajlik, mint a génállomány változása. Társadalmi, politikai, gazdasági, ökológiai stb. hatások ugyanis másként és másként befolyásolhatják nyelvek változásának módját és ütemét, s különféle nyelvi kontaktusok más és más nyelvi változásokhoz vezetnek. Tapasztalati tény, hogy valamely beszélöi közösség különféle hatások következtében három generáció alatt lecserélheti a nyelvét, ám a mai migrációs körülmények között ehhez akár két generáció is elegendő.

Ezért a fentiek értelmében genetikai azonosságokból vagy hasonlóságokból következtetni egy közösség nyelvére, nyelvi rokonságára, vagy éppen megfordítva, szinte lehetetlenség, hiszen nyelv és génállomány között nem áll fenn oksági viszony. Ha egy közösség változatos okokból két vagy több ágra szakadva felbomlik, és nyelvük eltávolodik egymástól, mint például az uráli nyelvcsalád esetében a finnugor és szamojéd ág, génjeik csak azt tükrözhetik, hogy valamikor közük lehetett egymáshoz, de azt már nem, hogy az együttélés idején „szamojéd nyelvi gének” vagy „finnugor nyelvi gének” jellemezték a később kialakuló ágak beszélöit.

Kivételeknek tekinthetők ezért azok az esetek, amikor egy beszélöközösség őrzi egy nyelvcsalád előzményének génállományát. Adatok mutatnak arra, hogy az ausztronéz nyelvek ${ }^{1}$ eredete földrajzilag Tajvanra tehető; az itt beszélt, erősen veszélyeztetett formosai nyelvek, melyek a nyelvcsalád többségét teszik ki, nem utolsósorban a matrilokális hagyományoknak köszönhetően őrzik az eredeti beszélőközösség genetikai tulajdonságait (Trejaut et al., 2005).

A következtetések lehetősége nem csupán a genetikai és nyelvi átörökítési folyamatok közötti különbségek következtében nehézkes, hanem a két tudományág, a genetika és a nyelvtörténet módszertani eltérései miatt is. A nyelvtörténet a maga hosszú ideje kidolgozott módszertanával - a nyelvi adatok természetéből következően - maximálisan hat-hét ezer évre képes visszatekinteni, a genetika viszont nagyságrendekkel mélyebbre. Ezért, ha genetikai eszközökkel két populációról igazolható is, hogy egy több tízezer évvel ezelött létezett közös ős leszármazottai, nyelvi eredetük tekintetében bajos lenne bármit is mondani róluk. (Éppenséggel az is lehetséges, hogy valóban annak a valamikori népesség által beszélt nyelvnek a történeti változatait ôrzik.)

További módszertani problémát jelent, hogy a nyelvtörténeti összefüggéseknek csupán kicsiny hányada kvantifikálható. Számszerüsíteni például azt, hogy

\footnotetext{
${ }^{1}$ Az ötödik legnagyobb nyelvcsalád a világon, közel 391 millió beszélővel Délkelet-Ázsia szigetvilágában, Óceániában, Madagaszkáron, Tajvanon és az Andamán-szigeteken.
} 
rokon nyelvek egymástól mekkora rokonsági távolságra vannak, a nyelvtörténet számára szinte képtelen feladat. Ezzel szemben a genetika kvantitatív megközelítésmódjai, a számítógépes filogenetika együttműködése az evolúció statisztikai modellezésével az utóbbi évtizedekben a nyelvtörténettől (is) kvantifikálható adatokat vár el az összemérhetőség érdekében. Következésképpen bizonyos türelmetlenség figyelhető meg, ha ugyanis ilyenekkel a „,hagyományos” vagy „ortodox" nyelvtörténet nem tud szolgálni, akkor a genetika kénytelennek gondolja maga megkeresni vagy elóállítani a kvantifikált adatokat (vö. McMahon, A. McMahon, R., 2005, 125.). Azok azonban nem feltétlenül fogadhatók el a nyelvtörténet számára, $\mathrm{s}$ ennek oka könnyen átlátható. Nyelvek történeti változása nem mérhető fel és nem magyarázható nyelven belüli, azaz a nyelv rendszeréből adódó és nyelven kívüli (nyelvhasználati, kulturális, társadalmi stb.) okok szövevényes összefüggéseinek együttes tekintetbevétele és egymásra vonatkoztatása nélkül. Ennek az összefüggésrendszernek éppen e bonyolult volta az, ami kétségeket ébreszt, egyelöre legalábbis, kvantifikálhatóságukkal kapcsolatban.

Mindebből elhamarkodott lenne arra következtetni, hogy genetika és nyelvtörténet együttmúködése esélytelen lenne. Éppen hogy nem. E dolgozat célja egy-két tipikus példán keresztül egyrészt rámutatni a genetikai és nyelvi változások jobb megértését inkább gátló, semmint segítő próbálkozásokra (2.), másrészt bemutatni olyan törekvéseket, amelyek ígéretesek lehetnek mindkét tudományág számára (3.). ${ }^{2}$

2. Nyelveknek genetikai, azaz a nyelvrokonság kiderítését célzó vizsgálatai megfelelően nagy számú adatot igényelnek, mégpedig nem csupán a szókincs, hanem a fonológia, a morfológia, de még a szintaxis tekintetében is - ezt nem nyelvészek ritkán szokták figyelembe venni. Az adatok sokaságának szükséges volta könynyen megérthető a következő példa alapján.

Bármennyire változatosak legyenek is a beszédhangok, számukat az ember anatómiai, fiziológiai felépítése határozza meg. A beszédhangok, s közöttük is a jelentésmegkülönböztető szerepủek (például $b \boldsymbol{a} b-b \boldsymbol{a} b$ ) száma tehát nem lehet végtelen mennyiségü, azaz egymástól minden tekintetben igen távoli nyelvek is mutathatnak jelentős egyezéseket fonémaállományuk tekintetében. Ezen túlmenően a szavakban a hangok sorbarendeződési tulajdonságai is tanúskodhatnak hasonlóságokról. Ha pedig az összevetések során csupán csekély számú példán vizsgáljuk az egyezések lehetőségeit, könnyen előfordulhat, hogy egy sor hasonló

2 A magyar olvasóközönség vélhetően elsőként Luigi L. Cavalli-Sforza nevére asszociál, amikor humángenetika és nyelvcsaládok, nyelvek eredetének összefüggéseiröl hall vagy olvas. Elgondolásainak különféle aspektusú értékelései több helyen is megjelentek, közöttük kritikaiak is (például Bálint, 2008; Bateman et al., 1990; Honti, 2004), dolgozatom viszont más megközelítésekre céloz rámutatni. 
vagy éppen egymással teljes mértékben megegyező szóra bukkanunk, amelyekről könnyedén hihetnénk, hogy azok e nyelvek rokonsági kapcsolataira utalnak. Így például az angol bad 'rossz' szónak éppúgy nincs köze a modern perzsa bad 'rossz' szóhoz, mint ahogyan a görög mati 'szem' szónak sincs a maláj mata-hoz és a koreai man szónak sincs az angol man-hez, holott mindkettő 'ember, férfi' jelentésü (Hock, 1991, 557.).

Az adatok megválasztásának hiteles volta azonban csak az egyik szempont, a másik a mennyiségük. 1987-ben jelent meg Joseph Greenbergnek, a jeles tipológusnak az elgondolása az indián nyelvek rokonsági felosztásáról. Eszerint három rokonsági csoport különíthető el: az amerindián nyelvek nagy csoportja, valamint a na-dene és az eszkimó-aleut nyelveké, melyeknek beszélői három hullámban, egymástól függetlenül vándoroltak volna be az amerikai kontinensre. A klasszifikáció alapja azonban módszertanilag elhibázott volt, amennyiben nem számolt az összehasonlító nyelvészetnek imént leírt kívánalmaival. A probléma azután abból adódott, hogy a rákövetkező közel két évtizedben a genetikusok szinte kizárólag Greenberg felosztására támaszkodtak, amikor az őslakosság genetikai vizsgálati eredményeit Amerika nyelvi felosztásával hasonlították össze - miközben a nyelvtörténészek lényegében egybehangzóan utasították el a greenbergi elgondolást (például Bolnick et al., 2004; Campbell, 1997). Azóta persze számos korrekció született a genetikai vizsgálatokat illetően (például Hunley-Long, 2005; Salzano et al., 2005 stb.). Tegyük hozzá, hogy Greenberg eljárása nem csupán az indián nyelvek egymáshoz való viszonyának megállapítására alkalmatlan, hanem bármely egyéb nyelv esetében is, azaz módszerével a világ bármely két vagy több nyelve között könnyedén találhatnánk rokonsági összefüggést. Az ok, hogy miért volt oly vonzó a genetikusok számára Greenberg felosztása, nyilvánvaló: mindössze három nyelvi csoporttal és bevándorlási hullámmal számolni jóval egyszerübb, mint a jócskán többszörösükkel (lásd például Mithun, 1999), ráadásul e felosztásokra nézvést egyébként sincs konszenzus a nyelvtudományban.

Eleddig nem hozott értékelhető eredményeket az a próbálkozás sem, mely a nyelvtipológia és a népességgenetika egyfajta összefüggésére építve adna magyarázatot bizonyos nyelvi jelenségek kialakulására, illetve feltűnésére egyes nyelvekben. Léteznek olyan fonológiai vagy grammatikai tulajdonságok, melyek földrajzilag egymáshoz közel beszélt nyelvekre jellemzők. Az ilyeneknek egyike a tonalitás. A tonális nyelvek meghatározott grammatikai összefüggéseket nem toldalékolással vagy a szórend módosításával fejeznek ki, hanem a szavak, illetve szótagok hangmagasságának változtatásával. Mások mellett Délkelet-Ázsia és a szubszaharai Afrika számos nyelve tonális, hozzátéve, hogy a tonalitás nyelvtörténeti kategória is, hiszen nyelvekben keletkezhetik tonalitás, és el is tünhetik. Megfigyelték (Dediu-Ladd, 2007), hogy az agy növekedéséért és fejlödéséért felelős gének közül kettő (az ASPM és a Microcephalin) csökkent mértékben 
van jelen ${ }^{3}$ olyan haplocsoportokban, amelyek tonális nyelveket beszélnek. Mivel kizárható annak a lehetősége, hogy a vizsgálatba bevont nyelvek rokonsági viszonyban állnának egymással, kauzális összefüggést feltételeznek tonalitás és e genetikai sajátosság között. A szerzők dolgozatukat követően újra és újra felvetették annak lehetőségét (például Ladd et al., 2008), hogy a fenti megállapításnak nyelvtörténeti jelentősége is lehet, $\mathrm{s}$ a változás mechanizmusát tekintve arra az ismert tényre hivatkoznak, hogy a nyelvi változások egyik oka a generációk közötti nyelvátadásban van. Azok a populációk tehát, amelyeknek beszélői között a fenti genetikai eltérést mutatók is vannak, generációk sora után oly módon befolyásolhatják a nyelvet (értsd: válthatnak ki nyelvi változást), hogy az az említett egyéni eltérések túlsúlyát fogja mutatni az egyébként egészséges nyelvelsajtítók nyelvi változatában is. Másként fogalmazva: átalakul a nyelv rendszerének egy tartománya, a nyelv tonálissá válik. Ez az elgondolás akár logikus is lehet, a nyelvi változás terjedésének valóban ez az egyik módja. A probléma csak az, hogy nincsenek vizsgálatok, tapasztalatok arra nézvést, hogy akár a tonalitás, akár más, genetikai okhoz köthető nyelvi jelenség ily módon játszana szerepet a nyelvi változásokban. Márpedig ha valami nem zárható ki, akkor az még nem jelenti azt, hogy igazolható is.

3. Nyelvtörténet és genetika összefüggésének felderítésében van egy harmadik irány, amely jóval megalapozottabb és ígéretesebb. Jellemzője, hogy a nyelv horizontális kapcsolataira, azaz nyelvi kontaktusokra és velük oksági kapcsolatban lévő génkeveredésre koncentrál. További fontos ismérve, hogy kisebb kiterjedésü földrajzi területen szűkebb és jól körülhatárolható nyelvi jelenségeket vizsgál, s olyan idősíkot ölel fel, amely a „hagyományos” nyelvtörténet számára is belátható, értékelhetö.

Fentebb azt mondtuk, nyelv és génállomány között nem áll fenn oksági viszony, azaz megtörténhetik például, hogy míg a nyelv jelentősen megváltozik, a beszélők genetikai tulajdonságai hordozzák a valamikori összetartozás bizonyítékát. A nyelvi diverzitás Délkelet-Ázsia és különösen Óceánia szigetvilágában a legmagasabb. Szumba (Ciprussal körülbelül megegyező alapterületü) sziget Indonéziában. Lakói főleg partvidéki, laza hálózatú, maximum ezer föt számláló falvakban élnek, közülük egymástól távoli nyolcra terjedt ki a genetikai vizsgálat (Lansing et al., 2007, Cox et al., 2016). Az első betelepülések 40-45 000 évvel ezelőttre tehetők, a szigeten beszélt nyelvek pedig, amelyek a proto-szumbaira vezethetők vissza, jóval közelebbi rokonai egymásnak, mint bármely szigeten kívüli nyelvnek, s korai szétválásról tanúskodnak. Kb. 3500 évvel ezelőtt ázsiai földmüvelők települtek be a szigetre, hozták magukkal az ázsiai földrészről nyelveiket, s házasulások révén gyökeret vertek a vadászó-gyüjtögető őslakosok

\footnotetext{
${ }^{3}$ De nincsenek befolyással a normális agyméretre, mentális képességekre stb.
} 
között. Szumba nyelvi diverzitása figyelemre méltó, legalább hét nyelv különböztethető meg (URL1). A lakosság túlnyomó többsége egynyelvű, s még az egymáshoz közeli falvakra is eltérő nyelvek jellemzők, mely állapot egyrészt nyilván az említett korai szétválásnak és a valahai külső nyelvi kontaktusoknak köszönhető, másrészt pedig a falvak közötti csekély mobilitásnak. A sziget kulturális, nyelvi térképe tehát jelentősen átalakult, ám ennek az átalakulásnak a hatása a genetikai jellemzőkre relatíve csekély volt. Mert igaz ugyan, hogy a falvaknak megvannak a maguk genetikai sajátosságai, de mégis őrzik és felmutatják genetikai kapcsolatukat is.

Egy másik példa nyelvi kölcsönzés és genetikai kapcsolat összefüggését mutatja. A világ nyelveiben vannak olyan hangok, amelyek jellemzően valamely jól meghatározott földrajzi övezetben élő beszélői közösségek nyelveiben jelentkeznek (akár a fentebb említett tonalitás is). Ilyenek például az ún. csettintőhangok (elnevezésük sokatmondó [URL2]), melyek a dél-afrikai koiszan és néhány ugyancsak dél-afrikai bantu, valamint néhány kelet-afrikai nyelvre jellemzők, és még az észak-ausztráliai damin nyelvre is. Nyelvtörténeti adatok utalnak arra, hogy a bantu nyelvekben e mássalhangzók nem belső fejlődés vagy valamely korábbi nyelvállapotból való átöröklődés eredményei, hanem nyelvi kapcsolatoknak köszönhetök (Güldemann, 2007). A kérdés csupán az, hogy e feltevés milyen független tényezőkkel támasztható alá. Egyrészt a térségben végzett genetikai vizsgálatok (Barbieri et al., 2013; Bostoen-Sands, 2012), másrészt pedig a házasodási szokások arra utalnak, hogy e hangok koiszan nyelvi kapcsolatok eredményeként kerültek e bantu nyelvekbe, mégpedig női beszélők révén. (Tudvalévő ugyanis, hogy a házassági kapcsolatokban a koiszan feleség-bantu férj párosítás volt a szokásos, a fordítottja nem, s a génmegoszlások is ezt támasztják alá.) A bantu csettintőhangok eredetének továbbá van még egy olyan aspektusa is, amelyet nyelvtörténeti tekintetben alig tárgyalnak, jóllehet nem ismeretlen tényezőről van szó. A több bantu nyelvben is meglévő hlonipha nyelvi változat egy társadalmi normáktól elöírt, ritkulóban lévő, de nőktől még használt tiszteleti nyelv. Jellemzően a férj idősebb férfi rokonai, mindenekelőtt az após megszólítását, nevének kimondását vagy e névre hasonlító egyéb szavak használatát tiltja (Zungu, 1997), azaz tabu-korlátozást jelent, melynek áthágása a nyelvi moralitás megszegését jelenti (Bakró-Nagy, 2015). A tiltott nevek, szavak használatának elkerülésére általában különféle stratégiák léteznek, így például a hangsor valamely elemének megváltoztatása. Tekintettel arra, hogy a matrilokális hagyományok értelmében a koiszan nő a férj bantu háztartásának tagjává válik, el kell sajátítania új környezete nyelvét is, annak minden használati szabályával együtt. Az elmondottakból a genetikai vizsgálatokkal egybehangzó nyelvtörténeti folyamatok már könnyen érthetők: az eredetileg ismeretlen csettintőhangoknak bantu nyelvekbéli elterjedésében a nyelvi tabu előírásai nem kizárólagos, de nem is elhanyagolható tényezőkként jelentkeztek. 
A fentiekből talán kitünik, hogy genetika és nyelvtörténet együttmüködése, feltéve a megközelítések körültekintő voltát, s mindenekelőtt azt, hogy nem várunk el a priori párhuzamosságokat nyelvtörténeti és genetikai változások között, mindkét tudományág számára gyümölcsöző lehet. De csak abban az esetben - s ez az az elvárás, amelyet minden, a kérdéskörrel foglalkozó nyelvészeti leírás hangsúlyoz -, ha valóban együttmüködésben folynak a vizsgálatok, s nem egymástól függetlenül.

\section{IRODALOM}

Bakró-Nagy M. (2015): A nyelvi tabu. In: Szeverényi S. - Szécsényi T. (szerk.): Érdekes nyelvészet. Szeged: JATEPress, 9-21. https://www.academia.edu/28161308/A nyelvi tabu

Bálint Cs. (2008): A történeti genetika és az eredetkérdés(ek). (A közös kutatás szükségessége és lehetőségei.) Magyar Tudomány, 169, 10, 1170-1187. http://www.matud.iif.hu/2008-10.pdf

Barbieri, C. - Butthof, A. - Bostoen, K. - Pakendorf, B. (2013): Genetic Perspectives on the Origin of Clicks in Bantu Languages from Southwestern Zambia. European Journal of Human Genetics, 21, 430-436. DOI:10.1038/ejhg.2012.192, https://www.nature.com/articles/ejhg2012192

Bateman, R. - Goddard, I. - O'Grady, R. et al. (1990): Speaking of Forked Tongues. Current Anthropology, 31, 1, 1-24. http://botany.si.edu/bdg/pdf/funkyarchive/funkypdf/1990_pr_ Bateman_etal_Tongues.pdf

Bolnick, D. A. - Shook, B. - Campbell, L. - Goddard, I. (2004): Problematic Use of Greenberg's Linguistic Classification of the Americas in Studies of Native American Genetic Variation. The American Journal of Human Genetics, 75, 519-523. https:/www.ncbi.nlm.nih.gov/pmc/ articles/PMC1182033/

Bostoen, K. - Sands, B. (2012): Clicks in South-western Bantu Languages: Contact-induced vs. Language-internal Lexical Change. In: Brenzinger, M. - Fehn, A.-M. (eds.): Proceedings of the $6^{\text {th }}$ World Congress of African Linguistics, Cologne 2009. Köln: Rüdiger Köppe Verlag, 129-140. https://goo.gl/oE2nmU

Campbell, L. (1997): American Indian Languages: The Historical Linguistics of Native America. New York: Oxford University Press

Cox, M. P. - Hudjashov, G. - Sim, A. et al. (2016): Small Traditional Human Communities Sustain Genomic Diversity over Microgeographic Scales despite Linguistic Isolation. Molecular Biology and Evolution, 33, 9, 2273-2284. DOI: 10.1093/molbev/msw099, http://mbe.oxfordjournals. org/content/early/2016/06/29/molbev.msw099

Dediu, D. - Ladd, R. (2007): Linguistic Tone Is Related to the Population Frequency of the Adaptive Haplogroups of Two Brain Size Genes, ASPM and Microcephalin. Proceedings of the National Academy of Sciences of the USA, 104, 10944-10949. DOI: 10.1073pnas.0610848104, http://www.pnas.org/content/104/26/10944.full.pdf

Greenberg, J. H. (1987): Language in the Americas. Stanford: Stanford University Press

Güldemann, T. (2007): Clicks, Genetics, and "proto-world" from a Linguistic Perspective. (University of Leipzig Papers on Africa. Languages and Literatures Series No. 29) Leipzig: Universität Leipzig, https://www.researchgate.net/publication/40853197_Clicks_genetics_and_proto-world_from_a_linguistic_perspective

Hock, H. H. (1991): Principles of Historical Linguistics. Berlin-New York: Mouton de Gruyter

Honti L. (2004): Mítoszok a magyar nyelv eredete körül. Nyelvtudományi Közlemények, 101, 137151. http://www.nytud.hu/nyk/101/hontimitoszok.pdf 
Hunley, K. - Long, J. C. (2005): Gene Flow across Linguistic Boundaries in Native North American Populations. Proceedings of the National Academy of Sciences of the USA, 102, 1312-1317. DOI: 10.1073/pnas.0409301102, http://www.pnas.org/content/102/5/1312.full

Ladd, D. R. - Dediu, D. - Kinsella, A. R. (2008): Languages and Genes: Reflections on Biolinguistics and the Nature-Nurture Question. Biolinguistics, 2, 1, 114-126. http://www.biolinguistics. eu/index.php/biolinguistics/article/view/39/61

Lansing, J. S. - Cox, Murray P. - Downey, Sean S. et al. (2007): Coevolution of Languages and Genes on the Island of Sumba, Eastern Indonesia. Proceedings of the National Academy of Sciences of the USA, 104, 16022-16026. DOI: 10.1073/pnas.0704451104, http://www.pnas.org/ content/104/41/16022.full

McMahon, A. - McMahon, R. (2005): Language Classification by Numbers. Oxford: Oxford University Press

Mithun, M. (1999): The Languages of Native North America. Cambridge: Cambridge University Press

Salzano, F. M. - Hutz, M. H. - Salamoni, S. P. et al. (2005): Genetic Support for Proposed Patterns of Relationship among Lowland South American Languages. Current Anthropology, 46, 121-128. DOI: 10.1086/497667, http://www.journals.uchicago.edu/doi/full/10.1086/497667

Trejaut, J. A. - Kivisild, T. - Loo, J.-H. - Lin, M. (2005): Traces of Archaic Mitochondrial Lineages Persist in Austronesian-Speaking Formosan Populations. PLOS Biology, 3/8: e247. DOI=10.1371\%2Fjournal.pbio.0030247, http://journals.plos.org/plosbiology/article?id=10.1371/ journal.pbio.0030247

Zungu, P. (1997): Some Aspects of Hlonipha in Zulu Society. Language Matters: Studies in the Languages of Africa, 28, 1, 171-181. DOI: 10.1080/1022819970856612

URL1: http:/glottolog.org/resource/languoid/id/sumb1243

URL2: https://www.youtube.com/watch?v=31zzMb3U0iY 